\title{
New Structures of Vector Control Systems for Permanent-Magnet Synchronous Motors with Core Loss
}

\author{
Shinji Shinnaka Member (Kanagawa University, shinnaka@ kanagawa-u.ac.jp)
}

Keywords: synchronous motor, core loss, vector control, structure, current control

This paper investigates and proposes new system structures for vector control of permanent-magnet synchronous motors (PMSMs) with core loss. The proposed vector control systems have the following versatile features. (a) The systems employ the structures allowing control of the stator current through control of the load current. (b) The systems employ unique "stator voltage feedback-use" structures in order to accomplish simply the load current control. (c) The produced torque is directly related to the load current, and the precise torque control can be attained through the load current control. (d) The relation between produced torque and the load current is nonlinear for salient-pole PMSMs similarly to the case of no core loss, and a variety of the load current commands can be selected from viewpoints of minimum loss and/or wide speed range drives. The system structures add no constraints to the selection of the load current commands. (e) In addition to the torque control, the speed control can be allowed, where linearity between output of the speed controller and produced torque is kept. The validity of versatile features is verified through the numerical experiments.

Figure 1 shows one of the proposed structures of vector control systems where "Load Current Evolver" produces the load current using stator voltage command and stator current, and "Current Controller" controls the load current according to its command. Figure 2 shows the structure of the Load Current Evolver where $R_{1}, R_{c}$ are stator winding resistance and equivalent core-loss resistance, respectively. Figure 3 shows a response example at speed of $180(\mathrm{rad} / \mathrm{s})$ where waveforms mean, from the top, q-stator current, q-load current, produced torque, d-load current, and d-stator current. Through the control of the load current, both of stator current and torque are well controlled.

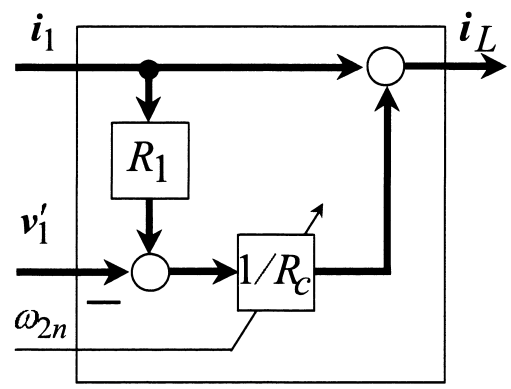

Fig. 2. A basic structure of load current evolver

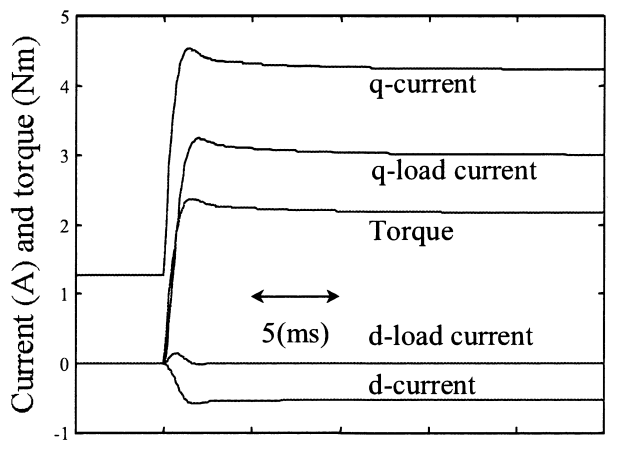

Time (ms)

Fig. 3. Response examples of current control at speed of $180(\mathrm{rad} / \mathrm{s})$

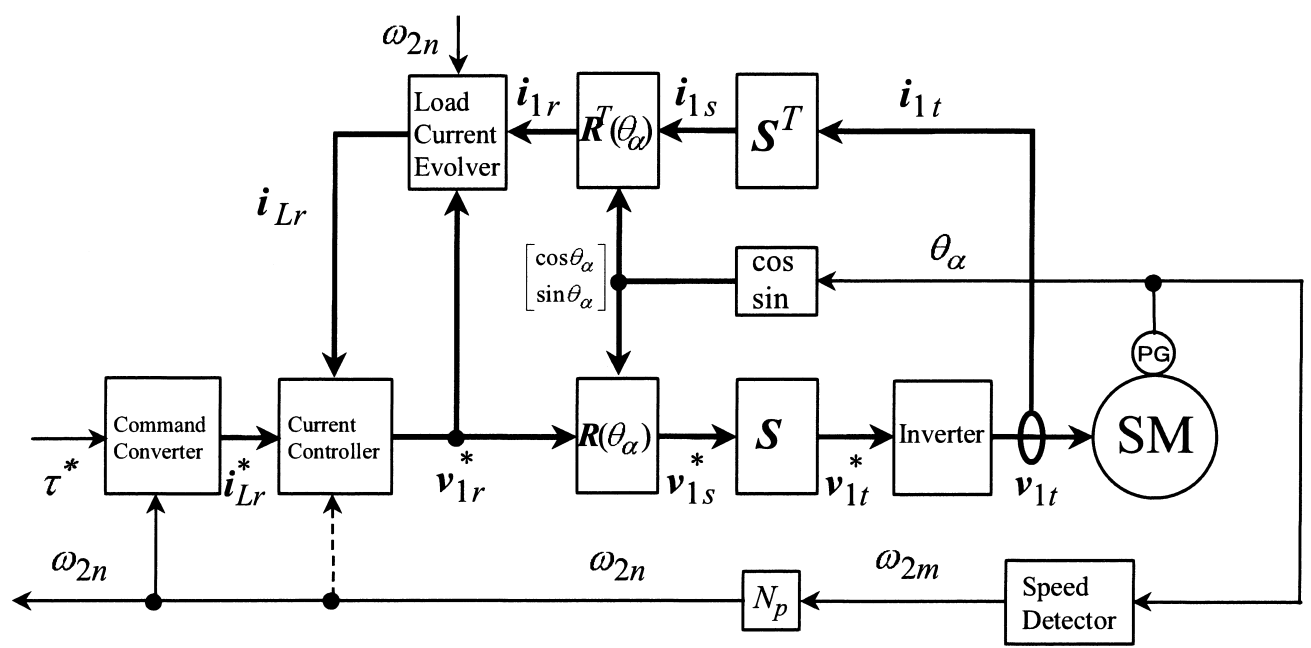

Fig. 1. A basic structure of vector control systems using the load current evolver in the rotor reference frame 


\title{
鉄損を有する永久磁石同期モータのための \\ ベクトル制御系の新構造
}

\author{
正 員 新中 新二* \\ New Structures of Vector Control Systems for Permanent-Magnet \\ Synchronous Motors with Core Loss
}

Shinji Shinnaka*, Member

\begin{abstract}
This paper investigates and proposes new system structures for vector control of permanent-magnet synchronous motors (PMSMs) with core loss. The proposed vector control systems have the following versatile features. (a) The systems employ the structures allowing control of the stator current through control of the load current. (b) The systems employ unique "stator voltage feedback-use" structures in order to accomplish simply the load current control. (c) The produced torque is directly related to the load current, and the precise torque control can be attained through the load current control. (d) The relation between produced torque and the load current is nonlinear for salient-pole PMSMs similarly to the case of no core loss, and a variety of the load current commands can be selected from viewpoints of minimum loss and/or wide speed range drives. The system structures add no constraints to the selection of the load current commands. (e) In addition to the torque control, the speed control can be allowed, where linearity between output of the speed controller and produced torque is kept. The validity of versatile features is verified through the numerical experiments.
\end{abstract}

キーワード：同期モータ，鉄損，ベクトル制御，構造，電流制御

Keywords: synchronous motor, core loss, vector control, structure, current control

\section{1. はじめに}

突極特性を有する永久磁石同期モー夕 (Salient-Pole Permanent-Magnet Synchronous Motor, SP-PMSM) の産 業界における利用が，その効率の良さから，近年一層の広 がりを見せている。利用拡大の中で，SP-PMSM の鉄損を 考慮した，より精密なべクトル制御法の研究が進められて いる(1) (5)。

SP-PMSM に所期のトルク発生をさせるには, ベクトル 制御法によることになる。ベクトル制御法は, SP-PMSM の数学モデルに立脚して構成されるため, 鉄損を考慮した ベクトル制御法の構築には, 先ずこの数学モデルが必要と なる。磁気回路で発生する損失である鉄損は，等価的に電 気回路上の抵抗による損失としてモデリングするのが実際 的である。この種のモデリングとしては，電磁鋼板自体の モデリングと同様に ${ }^{(16)}$, 固定子巻線に対して並列的に等価 鉄損抵抗を配するものと ${ }^{(1) \sim(12)}$, 直列的に配するものとが考

\footnotetext{
*神奈川大学工学部電子情報フロンテイア学科

干 221-8686 横浜市神奈川区六角橋 3-27-1

Dept. of Electrical Engineering, Kanagawa University

3-27-1, Rokkakubashi, Kanagawaku, Yokohama 221-8686
}

えられる ${ }^{(13) \sim(15)}$ 。

前者に関しては, 童・森本らの先駆的な提案に続き(4)(5), 数学的完成度の高いモデルとして, モータ内の電気磁気的 動特性を表現した回路方程式 (第 1 基本式), トルク発生の 瞬時関係を表現したトルク発生式 (第 2 基本式), エネル ギー伝達の動特性を表現したエネルギー伝達式（第 3 基本 式）の 3 つの整合性のとれた基本式からなる $\gamma \delta$ 一般座標 系上の動的数学モデルが, 新中により提案されている(1)(2)。 後者に関しては, 水野により提案された誘導電動機のモデ リング方法を ${ }^{(17)}$ SP-PMSM に応用した数学モデルが, 千住 らにより提案されている(13) (15)。

鉄損を考慮した数学モデル構築後の制御上の主たる課題 は，(a) 電流制御系を中核としたべクトル制御系の構造決定 と, (b) 構造決定したベクトル制御系に適用可能な, 高効率 あるいは広範囲駆動のための電流指令法（すなわち，電流 制御のための電流指令生成法) の確立にある。並列形数学 モデルに立脚したベクトル制御系としては, 童・森本ら提 案のもの (4)(5), Panaitescu ら提案のもの ${ }^{(6)}$, Monajemy ら提 案のもの ${ }^{(7)}$, Mademlis ら提案のもの ${ }^{(9)}$, Cavallaro ら提案 のもの (10)(11) などがある。これらべクトル制御系の構造は, 電流制御系の上位に速度制御系構成を条件にしたもの, ト 
ルク制御にも適用可能なものなどその細部は異なるが, 次 のような共通点を有している。

(a) 鉄損を無視した従来のベクトル制御法に利用された 電流制御系を，基本的にそのまま利用する。すなわ ち, 固定子電流の $\mathrm{d}$ 軸, $\mathrm{q}$ 軸成分制御のための電流 制御系の構造に関しては，変更はしない。

(b) 固定子電流の d 軸, $\mathrm{q}$ 軸成分制御のための電流指令 生成を担うブロックを, 鉄損を考慮の上, 高効率駆 動あるいは広範囲駆動の観点から，別途用意する。

(c) 電流指令生成ブロックの構築には, 固定子電圧の情 報は利用しない。

従来のベクトル制御系の構造的な相違は, 上記 (b) 項にお ける電流指令生成ブロックの細部構造（すなわち, 電流指 令生成法）にある。換言するならば, 従来の報告では, 概し て, 電流指令生成ブロックの細部構造に注意が払われ，鉄 損を考慮したべクトル制御系のあるべき構造に関しては, 必ずしも十分な検討がなされていないようである(1) (15)。

本論文は，SP-PMSMのための鉄損を考慮したべクトル 制御系のあるべき構造を検討し, 新たな構造を提案するも

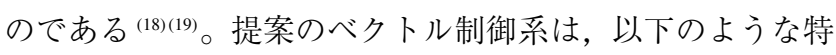
徴を有する。

(a) 提案ベクトル制御系は, 固定子電流を, 固定子鉄損を 担う固定子鉄損電流とトルク発生を担う固定子負荷 電流とに等価的に分離した並列形数学モデルの中で も, 数学的完成度の高い最新のモデルに立脚して ${ }^{(1)(2)}$, 固定子負荷電流の制御を通じて固定子電流を制御す る構造を採用している。

(b) 提案ベクトル制御系は, 固定子負荷電流制御の平易 な遂行を実現すべく固定子電圧を常時フィードバッ ク利用する構造を採用している。

（c）固定子負荷電流と発生トルクとは, 鉄損を無視でき る場合の固定子電流と発生トルクと同様の関係にあ り, 提案構造では, 鉄損分を排除した固定子負荷電 流の制御を通じ，精度の高いトルク制御が可能とな る (付録参照) ${ }^{(2) \sim(15)}$ 。

（d）トルク指令值から負荷電流指令值の生成を担う電流 指令法に関しては, ベクトル制御系の構造に起因す る制約はなく，種々のものが利用可能である。

(e) 提案ベクトル制御系は, トルク制御と同時に, 速度 制御にも利用可能である。提案べクトル制御系の上 位に速度制御系を構成する場合には，トルク指令值 （速度制御器の出力）とトルク応答值の間に線形性が 維持できるので, 線形性の良い速度制御系の構成が 可能となる。

本論文は, 以下のように構成されている。次の第 2 章で は, ベクトル制御系の構造決定の基礎となるSP-PMSM の数 学モデルを整理する。第 3 章では, 数学モデルに立脚したべ クトル制御系として, 電圧形負荷電流発生器 (load current evolver), または電圧形電流指令器 (current commander) を用いた 2 種の構造を新規提案する。これらは共に, 固定
子電圧を常時フィードバック利用する構造となっている。 第 4 章では, 提案構造のベクトル制御系によれば, トルク 発生に寄与する固定子負荷電流が直接的に制御され, 更に は本制御を通じ, 固定子電流が自動的に制御されることを, 数值実験を通じ検証・確認する。第 5 章で, 本論文を総括 する。

（注 1) 本論文では, 混乱の恐れのない限り, 記号 $s$ を微分 演算子 $d / d t$, またはラプラス演算子として, 断りな く使用する。

\section{SP-PMSM の数学モデル}

〈2・1〉動的数学モデル 図 1 のように, 任意の瞬時 速度 $\omega_{\gamma}$ で回転する $\gamma \delta$ 一般座標系を考える。同図には, $\alpha \beta$ 固定座標系, $\mathrm{dq}$ 同期座標系も参考までに表示している。ま た, SP-PMSM の回転子 $\mathrm{N}$ 極が主軸 $\gamma$ 軸に対し, ある瞬時 に位相 $\theta_{\gamma}$ をなしているものとする。

無視できない鉄損を有する SP-PMSM の数学モデルは, $\gamma \delta$ 一般座標系上の次の (1) (4) 式で記述することができ る $^{(1)(2)}$ 。

\section{【SP-PMSM の動的数学モデル】 回路方程式（第 $\mathbf{1}$ 基本式）}

$$
\begin{aligned}
\boldsymbol{v}_{1}= & \left(R_{1}+R_{c}\right) \boldsymbol{i}_{1}-R_{c} \boldsymbol{i}_{L} \ldots \ldots \ldots \ldots \ldots \ldots \ldots \\
\boldsymbol{v}_{1}= & R_{1} \boldsymbol{i}_{L}+\left(\frac{R_{1}+R_{c}}{R_{c}}\right) \\
& \cdot\left[\boldsymbol{D}\left(s, \omega_{\gamma}\right)\left[L_{i} \boldsymbol{I}+L_{m} \boldsymbol{Q}\left(\theta_{\gamma}\right)\right] \boldsymbol{i}_{L}+\omega_{2 n} \boldsymbol{J} \boldsymbol{\phi}_{m}\right] \ldots \ldots
\end{aligned}
$$

トルク発生式（第 2 基本式）

$$
\tau=N_{p} \boldsymbol{i}_{L}^{T} \boldsymbol{J}\left[L_{m} \boldsymbol{Q}\left(\theta_{\gamma}\right) \boldsymbol{i}_{L}+\boldsymbol{\phi}_{m}\right]
$$

エネルギー伝達式（第 3 基本式）

$$
\begin{aligned}
\boldsymbol{i}_{1}^{T} \boldsymbol{v}_{1}= & R_{1}\left\|\boldsymbol{i}_{1}\right\|^{2}+R_{c}\left\|\boldsymbol{i}_{1}-\boldsymbol{i}_{L}\right\|^{2}+\frac{s}{2}\left(\boldsymbol{i}_{L}^{T} \boldsymbol{\phi}_{i}\right)+\omega_{2 m} \tau \\
= & R_{1}\left\|\boldsymbol{i}_{1}\right\|^{2}+R_{c}\left\|\boldsymbol{i}_{1}-\boldsymbol{i}_{L}\right\|^{2} \\
& +\frac{s}{2}\left(L_{i}\left\|\boldsymbol{i}_{L}\right\|^{2}+L_{m}\left(\boldsymbol{i}_{L}^{T} \boldsymbol{Q}\left(\theta_{\gamma}\right) \boldsymbol{i}_{L}\right)\right)+\omega_{2 m} \tau
\end{aligned}
$$

ここに, $2 \times 1$ ベクトル $v_{1}, i_{1}, i_{L}$ は，それぞれ固定子電圧， 固定子電流, 固定子負荷電流 (固定子電流の負荷側等価流

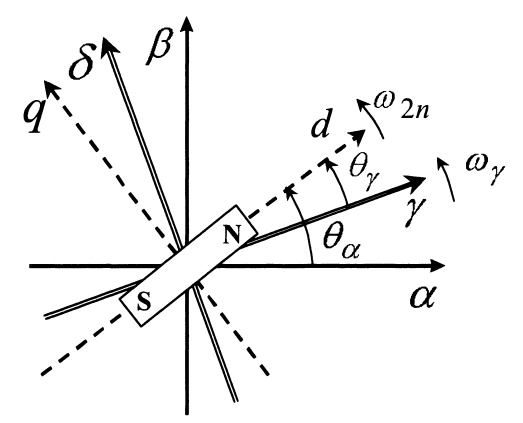

図 1 座標系と回転子位相の関係

Fig. 1. Three reference frames and rotor phase. 
入分）を意味している。 $2 \times 1$ ベクトル $\phi_{i}, \phi_{m}$ は, 各々, 固 定子負荷電流 $\boldsymbol{i}_{L}$ によって誘導発生した固定子反作用磁束, 回転子永久磁石に起因する回転子磁束であり，次のように 記述される。

$$
\begin{aligned}
& \boldsymbol{\phi}_{i}=\left[L_{i} \boldsymbol{I}+L_{m} \boldsymbol{Q}\left(\theta_{\gamma}\right)\right] \boldsymbol{i}_{L} \ldots \ldots \ldots \\
& \boldsymbol{\phi}_{m}=\Phi\left[\begin{array}{c}
\cos \theta_{\gamma} \\
\sin \theta_{\gamma}
\end{array}\right] ; \quad \Phi=\mathrm{const}
\end{aligned}
$$

$\phi_{1}$ を固定子鎖交磁束とするとき，次の関係が成立している。

$$
\phi_{1}=\phi_{i}+\phi_{m}
$$

また, $\boldsymbol{I}$ は $2 \times 2$ 単位行列であり, $\boldsymbol{J}$ は次式で定義された $2 \times 2$ 交代行列である。

$$
\boldsymbol{J}=\left[\begin{array}{cc}
0 & -1 \\
1 & 0
\end{array}\right]
$$

$\omega_{2 n}$ は回転子の電気速度であり, $R_{1}, R_{c}$ は各々固定子の等 価的な銅損抵抗 (巻線抵抗), 鉄損抵抗である。 $L_{i}, L_{m}$ は 固定子の同相インダクタンス, 鏡相インダクタンスであり, $\mathrm{d} ， \mathrm{q}$ インダクタンスとは次の関係を有する。

$$
\left[\begin{array}{l}
L_{d} \\
L_{q}
\end{array}\right]=\left[\begin{array}{cc}
1 & 1 \\
1 & -1
\end{array}\right]\left[\begin{array}{l}
L_{i} \\
L_{m}
\end{array}\right]
$$

また, $\boldsymbol{Q}(\cdot), \boldsymbol{D}(\cdot, \cdot)$ は，各々以下のように定義された鏡行 列，D因子である。

$$
\begin{aligned}
& \boldsymbol{Q}\left(\theta_{\gamma}\right)=\left[\begin{array}{cc}
\cos 2 \theta_{\gamma} & \sin 2 \theta_{\gamma} \\
\sin 2 \theta_{\gamma} & -\cos 2 \theta_{\gamma}
\end{array}\right] . \\
& \boldsymbol{D}\left(s, \omega_{\gamma}\right)=s \boldsymbol{I}+\omega_{\gamma} \boldsymbol{J} \ldots \ldots \ldots
\end{aligned}
$$

$\langle\mathbf{2} \cdot \mathbf{2}\rangle$ 等価抵抗の鉄損表現能力 上記数学モデルが, 単なる損失ではなく，固定子鉄損の特性を備えた損失を適 切に表現し得ることが既に明らかにされている(1)(2)。ここ では,この要点を整理しておく。

固定子鎖交磁束のノルムが一定の場合，すなわち $\left\|\boldsymbol{\phi}_{1}\right\|=$ const が成立する場合には，固定子鎖交磁束の瞬時周波数を $w_{1 f}$ とすると, 次の関係が成立する。

$$
\begin{gathered}
\boldsymbol{D}\left(s, \omega_{\gamma}\right) \boldsymbol{\phi}_{1}=\omega_{1 f} \boldsymbol{J} \boldsymbol{\phi}_{1} ; \quad\left\|\boldsymbol{\phi}_{1}\right\|=\mathrm{const} \ldots \ldots \ldots \\
\left\|\boldsymbol{D}\left(s, \omega_{\gamma}\right) \boldsymbol{\phi}_{1}\right\|=\left|\omega_{1 f}\right|\left\|\boldsymbol{\phi}_{1}\right\| ; \quad\left\|\boldsymbol{\phi}_{1}\right\|=\mathrm{const} \ldots \ldots
\end{gathered}
$$

(4) 式の右辺第 2 項として示された等価鉄損抵抗による 損失（すなわち，鉄損）は，固定子鎖交磁束を用い次のよ うに評価することもできる。

$$
R_{c}\left\|i_{R}\right\|^{2}=\frac{1}{R_{c}}\left\|\boldsymbol{D}\left(s, \omega_{\gamma}\right) \boldsymbol{\phi}_{1}\right\|^{2} .
$$

ただし， $\boldsymbol{i}_{R}$ は，次式で定義された固定子鉄損電流（固定子 電流の鉄損側等価流入分）である。

$$
i_{R}=i_{1}-i_{L}
$$

(14) 式に $\left\|\phi_{1}\right\|=$ const の条件の下に(13) 式を用いると, 鉄 損評価式として次式を得る,

$$
R_{c}\left\|\boldsymbol{i}_{R}\right\|^{2}=\frac{\omega_{1 f}^{2}}{R_{c}}\left\|\phi_{1}\right\|^{2}
$$

特に，等価鉄損抵抗を次式に示すように 2 種の等価抵抗を 用い，より詳細に表現する場合には，

$$
\frac{1}{R_{c}}=\frac{1}{R_{c 0}}+\frac{1}{R_{c 1}\left|\omega_{1 f}\right|} ; \quad \begin{aligned}
& R_{c 0}=\text { const } \\
& R_{c 1}=\text { const }
\end{aligned}
$$

モデル上の鉄損は，次式のように評価される。

$$
R_{c}\left\|\boldsymbol{i}_{R}\right\|^{2}=\frac{\omega_{1 f}^{2}}{R_{c 0}}\left\|\boldsymbol{\phi}_{1}\right\|^{2}+\frac{\left|\omega_{1 f}\right|}{R_{c 1}}\left\|\boldsymbol{\phi}_{1}\right\|^{2}
$$

(18) 式の右辺第 1 項は固定子渦電流損を，第 2 項は固定 子ヒステリシス損を示すものとなっている。すなわち, モー タコアを構成する電磁鋼板の鉄損の主要素である渦電流損 とヒステリシス損との定常値に関しては, 渦電流損は 2 乗 磁束と 2 乗周波数の積に比例し，またヒステリシス損は 2 乗磁束と周波数の積に比例することが知られている。(18) 式は，電磁鋼板のこの鉄損特性を適切に表現しており，し かも，このときの等価鉄損抵抗 $R_{c 0}, R_{c 1}$ は基本的には定数 である。

\section{3. 電圧情報を利用した電流制御系の構造}

〈3.1〉 電圧形負荷電流発生器を用いた構造回路方 程式 (2) 式, トルク発生式 (3) 式において, 形式的に次の置 換を行うことを考える。

$$
i_{L} \rightarrow i_{1}, \quad \frac{R_{c}}{R_{1}+R_{c}} v_{1} \rightarrow v_{1}, \quad \frac{R_{1} R_{c}}{R_{1}+R_{c}} \rightarrow R_{1}
$$

上記の形式的な置換を施された回路方程式 (2) 式, トルク 発生式 (3) 式は，鉄損の影響を無視した回路方程式，トル ク発生式と同一になる。従って，固定子負荷電流 $\boldsymbol{i}_{L}$ が固定 子電流 $\boldsymbol{i}_{1}$ 同様利用可能であれば，固定子電流の各成分を独 立的に制御するための鉄損を無視したべクトル制御系の基 本構造が利用できることがわかる。固定子負荷電流 $\boldsymbol{i}_{L}$ は, 回路方程式 (1) 式より得た, 次の固定子電圧を用いた関係 に従い，算定可能である。

$$
\boldsymbol{i}_{L}=\boldsymbol{i}_{1}+\frac{1}{R_{c}}\left[R_{1} i_{1}-\boldsymbol{v}_{1}\right]
$$

上式は, $\mathrm{dq}$ 同期座標系, $\alpha \beta$ 固定座標系を特別の場合として 含む $\gamma \delta$ 一般座標系上で成立する関係であり, 更には, 定常 応答，過渡応答を含めた各瞬時に成立する関係である。ま た，本関係を支配するモータパラメー夕は，固定子巻線抵 抗と等価鉄損抵抗のみであり, 他のモータパラメー夕を要 しない。この点には注意されたい。

（20）式に基づく固定子負荷電流の算定には，固定子電圧, 固定子電流の情報が必要であるが，応用に際しては，これ ら実測值に代わって，これらの良好な近似值を利用してょ 
い。特に固定子電圧に関しては, システム構成簡略化の観 点から, 近似值の利用が実際的である。(20) 式は, 固定子 電圧の近似值 $\boldsymbol{v}_{1}^{\prime}$ を用いる場合には，次の実質的に等価な関 係に書き改められる。

$$
\boldsymbol{i}_{L}=\boldsymbol{i}_{1}+\frac{1}{R_{c}}\left[R_{1} i_{1}-\boldsymbol{v}_{1}^{\prime}\right]
$$

更に，固定子電流として同近似值 $i_{1}^{\prime}$ を利用する場合には， (20) 式は次の実質的に等価な関係に書き改められる。

$$
i_{L}=i_{1}+\frac{1}{R_{c}}\left[R_{1} i_{1}^{\prime}-v_{1}^{\prime}\right]
$$

(21), (22) 式における固定子電圧近似值 $\boldsymbol{v}_{1}^{\prime}$ としては，例 えば, 固定子電圧指令值, 固定子電圧指令值のフィルタ処 理值などが考えられる。すなわち，

$$
\begin{aligned}
\boldsymbol{v}_{1}^{\prime} & =\boldsymbol{v}_{1}^{*}(k-1) \\
\boldsymbol{v}_{1}^{\prime} & =G_{v}(s) \boldsymbol{v}_{1}^{*}
\end{aligned}
$$

(23a) 式は，電流制御系を離散時間的に構成する場合におい て, $\mathrm{k}$ 時点の固定子負荷電流を $(k-1)$ 時点の固定子電圧指 令值を利用して算定することを意味する。(23b) 式は, 厳に プロパーな (strictly proper，すなわち相対次数が 1 以上の) 伝達関数をもつフィルタ $G_{v}(s)$ で処理した固定子電圧指令 值を利用して，固定子負荷電流を算定することを意味する。 このときのフィルタ $G_{v}(s)$ は電流制御帯域幅より広い帯域 幅を持たせるようにすれば，フィルタ $G_{v}(s)$ が電流制御に 及ぼす影響は，実質的には無視できるようになる。フィル 夕 $G_{v}(s)$ は連続時間的に実現しても, 離散時間的に実現し てもよい。

図 2 は, 固定子電圧情報として同近似值を利用した (21) 式を, 電圧形負荷電流発生器 (load current evolver) として ブロック線図で表現したものである。なお，同図では，等 価鉄損抵抗 $R_{c}$ の周波数依存性（(17) 式参照）は実質的に は速度依存性と同一であるとして（すなわち，|$\left|\omega_{1 f}\right| \approx\left|\omega_{2 n}\right|$ として）電気速度 $\omega_{2 n}$ による貫徹矢印で表現している。

図 3 は，固定子負荷電流の算定に固定子電圧指令值を利 用した電圧形負荷電流発生器を用いて, 固定子負荷電流の $\mathrm{d}, \mathrm{q}$ 軸成分を独立的に制御するためのべクトル制御系の構 造を例示したものである。本図では, 電圧, 電流の信号に 関しては，座標系を明示すべく, uvw 座標系, $\alpha \beta$ 固定座標 系, $\mathrm{dq}$ 同期座標系に対応して脚符 $\mathrm{t}, \mathrm{s}, \mathrm{r}$ を付している。本 例では, 電圧形負荷電流発生器はベクトル回転器 $\boldsymbol{R}^{T}(\cdot)$ の 後に配置されており，この入出力信号は $\mathrm{dq}$ 同期座標系上 の信号である。換言するならば，電圧形負荷電流発生器は $\mathrm{dq}$ 同期座標系上で構成されている。

同図より，電圧形負荷電流発生器に関連して，固定子電 圧指令值が電流制御ループ内で再利用されている様子が明 らかであろう。このように，各電流成分の独立制御におい て, 固定子電圧をフィードバック的に再利用する点が，提 案構造の特徵である。電圧形負荷電流発生器に冠した「電 圧形」の所以はここにある。

図 3 のベクトル制御系における電流制御器としては, 基 本的に，鉄損を無視したべクトル制御のための電流制御器 (一般には, PI 制御器, 非干渉器) をそのまま利用すれば よい。非干渉器の構成には電流の $\mathrm{d}, \mathrm{q}$ 軸成分が必要である

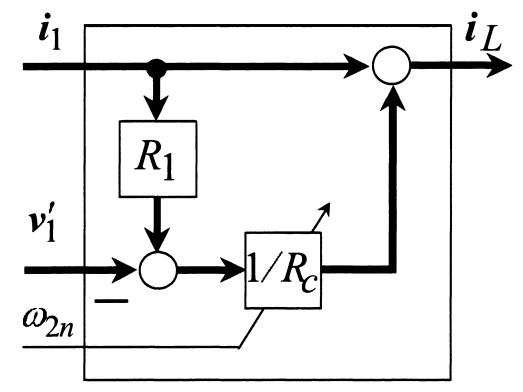

図 2 電圧形負荷電流発生器の概略構造

Fig. 2. A basic structure of load current evolver.

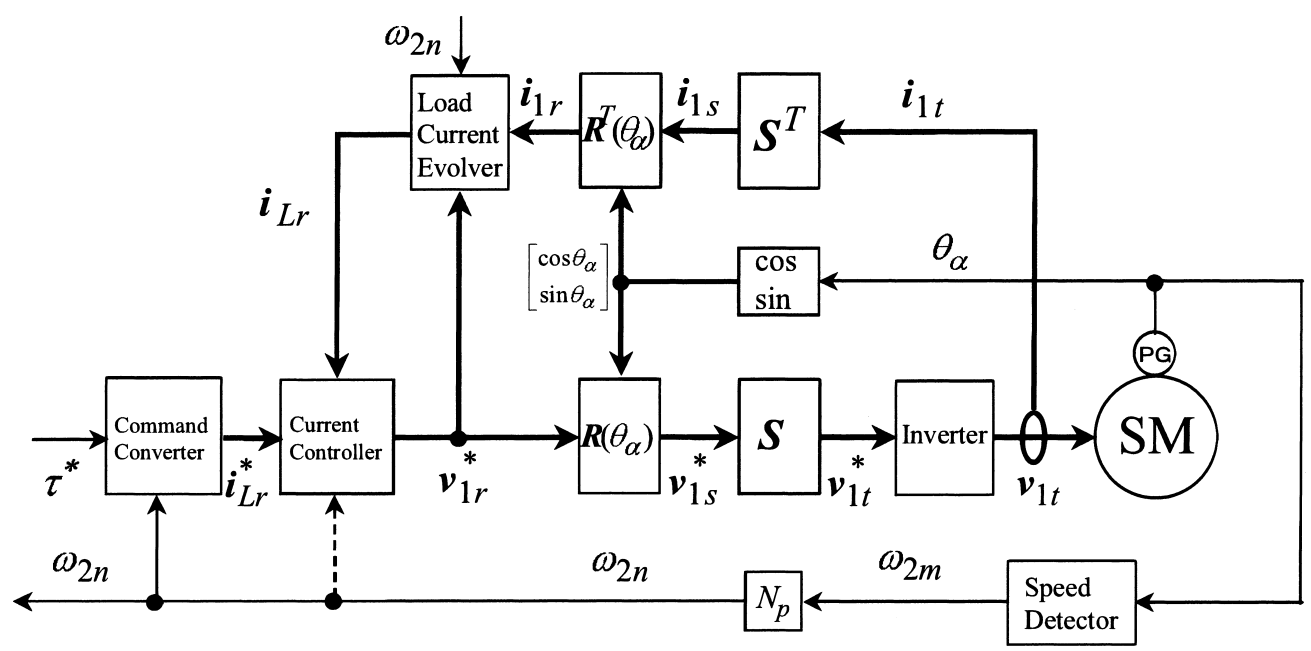

図 $3 \mathrm{dq}$ 同期座標系上で電圧形負荷電流発生器を用いたベクトル制御系の構造例

Fig. 3. A basic structure of vector control systems using the load current evolver in the rotor reference frame. 


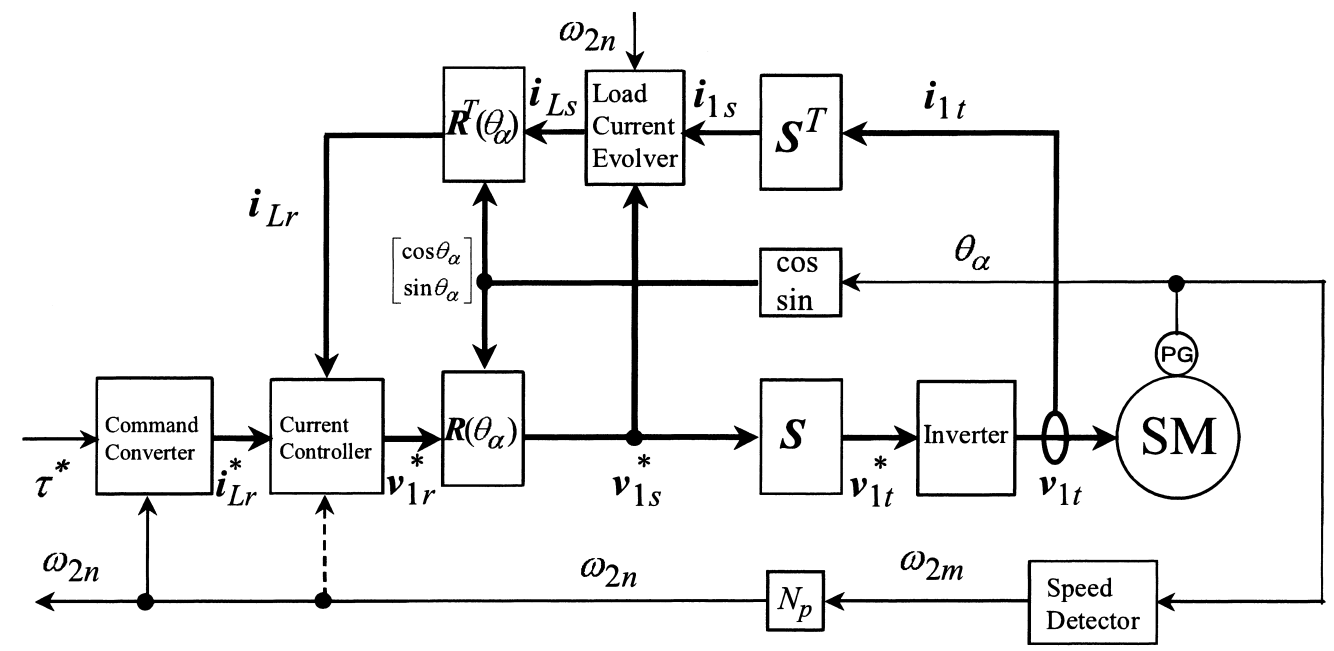

図 $4 \alpha \beta$ 固定座標系上で電圧形負荷電流発生器を用いたベクトル制御系の構造例

Fig. 4. A basic structure of vector control systems using the load current evolver in the stator reference frame.

が, 本電流としては, 固定子負荷電流, 固定子電流のいず れでもよい。すなわち,

$$
\begin{aligned}
& \tilde{\boldsymbol{v}}_{1}^{*}=\left(K_{p}+\frac{K_{i}}{s}\right)\left[i_{L}^{*}-\boldsymbol{i}_{L}\right] \cdots \\
& \boldsymbol{v}_{1}^{*}=\tilde{\boldsymbol{v}}_{1}^{*}+\left[\begin{array}{c}
-\omega_{2 n} L_{q} i_{L q} \\
\omega_{2 n}\left(L_{d} i_{L d}+\Phi\right)
\end{array}\right]
\end{aligned}
$$

または，

$$
\begin{aligned}
& \tilde{\boldsymbol{v}}_{1}^{*}=\left(K_{p}+\frac{K_{i}}{s}\right)\left[\boldsymbol{i}_{L}^{*}-\boldsymbol{i}_{L}\right] \cdots \\
& \boldsymbol{v}_{1}^{*}=\tilde{\boldsymbol{v}}_{1}^{*}+\left[\begin{array}{c}
-\omega_{2 n} L_{q} i_{q} \\
\omega_{2 n}\left(L_{d} i_{d}+\Phi\right)
\end{array}\right]
\end{aligned}
$$

上式に扮ける脚符 $\mathrm{d} ， \mathrm{q}$ は， $\mathrm{d} ， \mathrm{q}$ 軸成分を意味する。また， 若干の過渡応答の劣化を許容するならば，鉄損を無視した ベクトル制御の場合と同様に非干渉器の撤去も可能である。 すなわち

$$
\boldsymbol{v}_{1}^{*}=\left(K_{p}+\frac{K_{i}}{s}\right)\left[i_{L}^{*}-i_{L}\right]
$$

図 3 のベクトル制御系における電流制御器への入力信号 である固定子負荷電流と同指令值との偏差は，次式となる。

$$
\begin{aligned}
& i_{L}^{*}-i_{L}=i_{L}^{*}-\left[i_{1}+\frac{1}{R_{c}}\left[R_{1} i_{1}-v_{1}^{\prime}\right]\right] \\
& =\left[i_{L}^{*}+\frac{1}{R_{c}}\left[v_{1}^{\prime}-R_{1} i_{1}\right]\right]-i_{1}=i_{1}^{*}-i_{1} \\
& i_{1}^{*}=i_{L}^{*}+\frac{1}{R_{C}}\left[v_{1}^{\prime}-R_{1} i_{1}\right]
\end{aligned}
$$

(27)式におけるすべての信号は, dq 同期座標系上の信号で ある。

図 4 は, 電圧形負荷電流発生器を $\alpha \beta$ 固定座標系上で構 成した例である。固定子電圧指令值をフィードバック的に
再利用した電圧形負荷電流発生器の構成座標系の違いを除 けば，他は図 3 と同一である。この場合の電流制御器への 入力信号である固定子負荷電流と同指令值との偏差は, 次 式となる。

$$
\begin{aligned}
\begin{aligned}
& \boldsymbol{i}_{L}^{*}-\boldsymbol{i}_{L}=\boldsymbol{i}_{L}^{*}-\boldsymbol{R}^{T}\left(\theta_{\alpha}\right)\left[\boldsymbol{i}_{1 s}+\frac{1}{R_{c}}\left[R_{1} \boldsymbol{i}_{1 s}-\boldsymbol{v}_{1 s}^{\prime}\right]\right] \\
&=\left[\boldsymbol{i}_{L}^{*}+\frac{1}{R_{c}} \boldsymbol{R}^{T}\left(\theta_{\alpha}\right)\left[\boldsymbol{v}_{1 s}^{\prime}-R_{1} \boldsymbol{i}_{1 s}\right]\right]-\boldsymbol{i}_{1}=\boldsymbol{i}_{1}^{*}-\boldsymbol{i}_{1} \\
& \ldots \ldots \ldots \ldots \ldots \ldots(28 \mathrm{a})
\end{aligned} \\
\boldsymbol{i}_{1}^{*}=\boldsymbol{i}_{L}^{*}+\frac{1}{R_{c}} \boldsymbol{R}^{T}\left(\theta_{\alpha}\right)\left[\boldsymbol{v}_{1 s}^{\prime}-R_{1} \boldsymbol{i}_{1 s}\right] \\
=\boldsymbol{i}_{L}^{*}+\frac{1}{R_{c}}\left[\boldsymbol{v}_{1}^{\prime}-R_{1} \boldsymbol{i}_{1}\right] \ldots \ldots \ldots \ldots \ldots \ldots(28 \mathrm{~b}) \\
\boldsymbol{v}_{1}^{\prime}=\boldsymbol{R}^{T}\left(\theta_{\alpha}\right) \boldsymbol{v}_{1 s}^{\prime}, \quad \boldsymbol{i}_{1}=\boldsymbol{R}^{T}\left(\theta_{\alpha}\right) \boldsymbol{i}_{1 s} \ldots \ldots \ldots \ldots(28 \mathrm{c})
\end{aligned}
$$

(28) 式に㧍ける脚符 $\mathrm{s}$ は, 関連信号が $\alpha \beta$ 固定座標系上の 信号であることを意味する。(28) 式と (27) 式の比較より明 白なように, 眓 3, 図 4 に示した両システムは, (28c) 式の 関倸が保持されれば，同一の制御性能を有する。

図 3, 図 4 のシステム構造の基礎となった (20) 式は $\gamma \delta$ 一般座標系上の関係であるが，同様な関係は uvw 三相信号 の間でも成立し, 電圧形負荷電流発生器は uvw 座標系上で も構成可能である。この場合も，固定子負荷電流と同指令 值との偏差の評価を通じ，(27)，(28) 式と等価な偏差が得 られ，ひいては図 3 , 図 4 のシステムと同一の応答が得ら れる。

(20) 式と実質等価な関係にある (22) 式を利用し，固定子 電流近似值 $\boldsymbol{i}_{1}^{\prime}$ として同指令值を採用する場合には（すなわ $\left.ち i_{1}^{\prime}=i_{1}^{*}\right)$, 固定子負荷電流は, 次のように算定される。

$$
i_{L}=i_{1}+\frac{1}{R_{c}}\left[R_{1} i_{1}^{*}-v_{1}^{\prime}\right]
$$

この場合の電流制御器への入力信号である固定子負荷電流 と同指令值との偏差は，次式のように整理される。 


$$
\begin{array}{r}
i_{L}^{*}-i_{L}=i_{L}^{*}-\left[i_{1}+\frac{1}{R_{c}}\left[R_{1} i_{1}^{*}-v_{1}^{\prime}\right]\right] \\
=\left[i_{L}^{*}+\frac{1}{R_{c}}\left[v_{1}^{\prime}-R_{1} i_{1}^{*}\right]\right]-i_{1}=i_{1}^{*}-i_{1} \\
\ldots \ldots \ldots \ldots \ldots \ldots \ldots \ldots \ldots \ldots
\end{array}
$$

$\langle 3 \cdot 2\rangle$ 電圧形電流指令器を用いた構造鉄損の影響 を考慮して固定子電流指令值を発生するならば，固定子鉄 損を無視したべクトル制御系をそのまま活用できる。この ような固定子電流指令值の生成法は，高効率駆動法あるい は広範囲駆動法にリンクした形で，既に幾つか報告されて いる ${ }^{(4) \sim(12)}$ 。本節では，これら従来法と異なり，特定の高効 率駆動法あるいは広範囲駆動法に制約されない汎用性のあ る固定子電流指令法を提案する。

提案の方法は, 固定子負荷電流指令值のフィードフォワー ド利用と固定子電圧のフィードバック利用により，固定子 電流指令を生成するものである。(20) 式に基づき得られた (27) 式あるいは (30) 式は, 鉄損の影響を無視したべクト ル制御系において, 固定子電流指令值を(27b) 式あるいは (30b) 式のように生成したことと等価であることをも意味し ている。すなわち，(27b) 式あるいは (30b) 式を利用するな らば，特定の駆動法に制約されない汎用性のある形で，固 定子電流指令值を難なく発生できる。

図 5 は, 固定子負荷電流指令值を利用して固定子電流指令 值を発生するための電圧形電流指令器 (current commander) をブロック線図で表現したものである。同図の (a), (b) は, 各々 (27b) 式, (30b) 式に基づいており, 名称の所以となっ た固定子電圧情報を利用している。なお，同図では，電圧 形負荷電流発生器と同様に，等価鉄損抵抗 $R_{c}$ の周波数依存 性（(17) 式参照）は実質的には速度依存性と同一であると して（すなわち，|$\left|\omega_{1 f}\right| \approx\left|\omega_{2 n}\right|$ として）電気速度 $\omega_{2 n}$ によ る貫徹矢印で表現している。
図 6 に, 電圧形電流指令器によるべクトル制御系の構造 例を示した。図 5 に示したように, 電圧形電流指令器には 必ずしも固定子電流は必要ないので, 電圧形電流指令器へ の固定子電流入力は破線で示している。固定子電流の制限 は, 電圧形負荷電流発生器を利用したベクトル制御系, 電 圧形電流指令器を利用したベクトル制御系のいずれでも実 施可能であるが, 電圧形電流指令器を利用したベクトル制 御系は, 陽に固定子電流指令值を生成しており, 固定子電 流制限を実施しやすい構造になっている，と言える。

図 3, 図 4, 図 6 に例示した電圧形負荷電流発生器または 電圧形電流指令器を用いたべクトル制御系は, 固定子負荷 電流指令值を発生していることから理解されるように, 固 定子負荷電流の制御を介して固定子電流を制御するもので

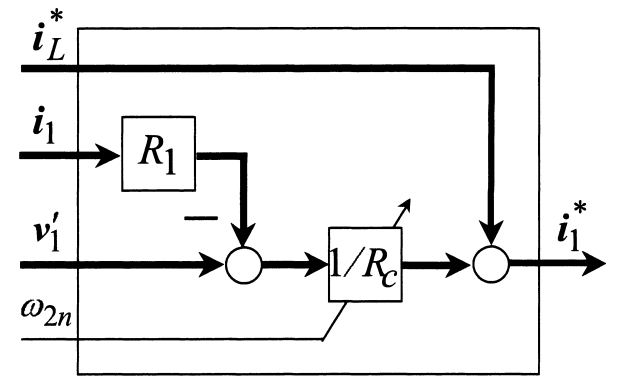

(a)

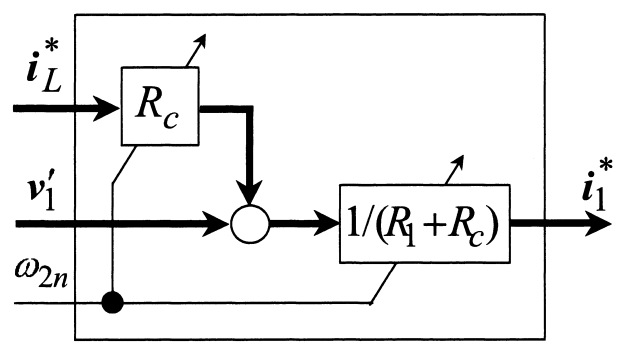

(b)

図 5 電圧形電流指令器の構成例

Fig. 5. A basic structure of current commander.

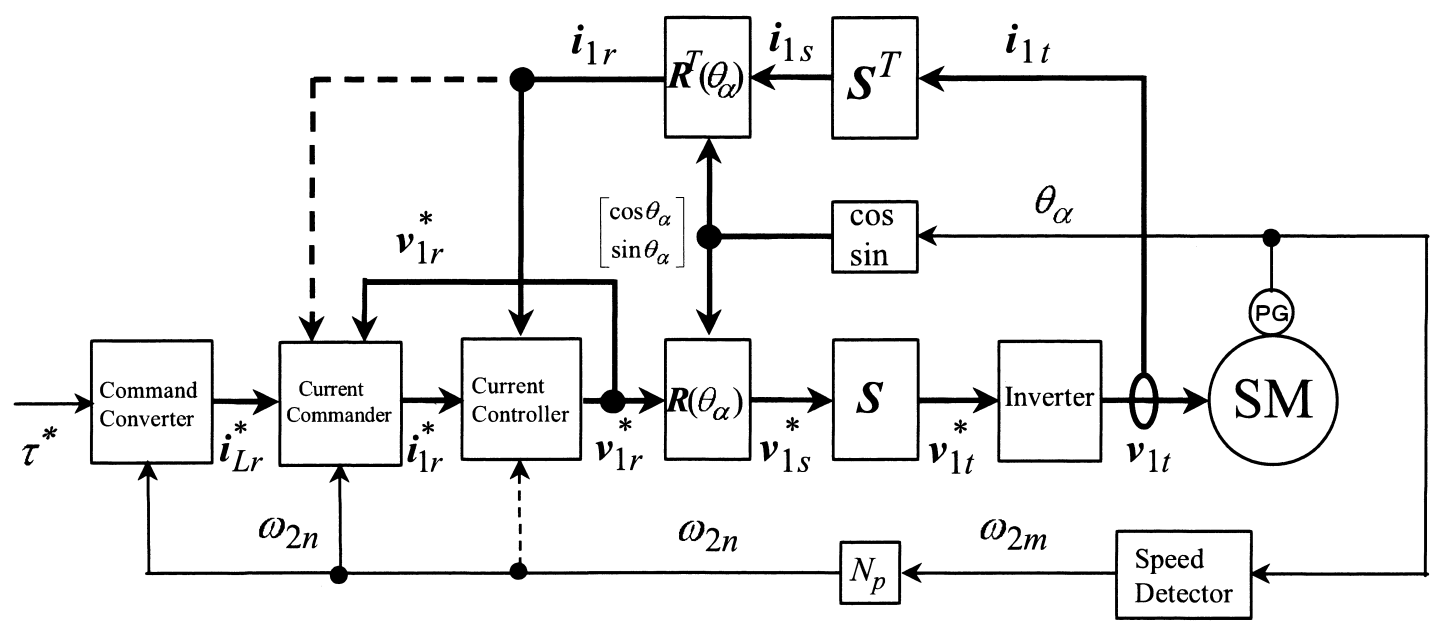

図 6 電圧形電流指令器を用いたベクトル制御系の構造例

Fig. 6. A basic structure of vector control systems using the current commander in the rotor reference frame. 


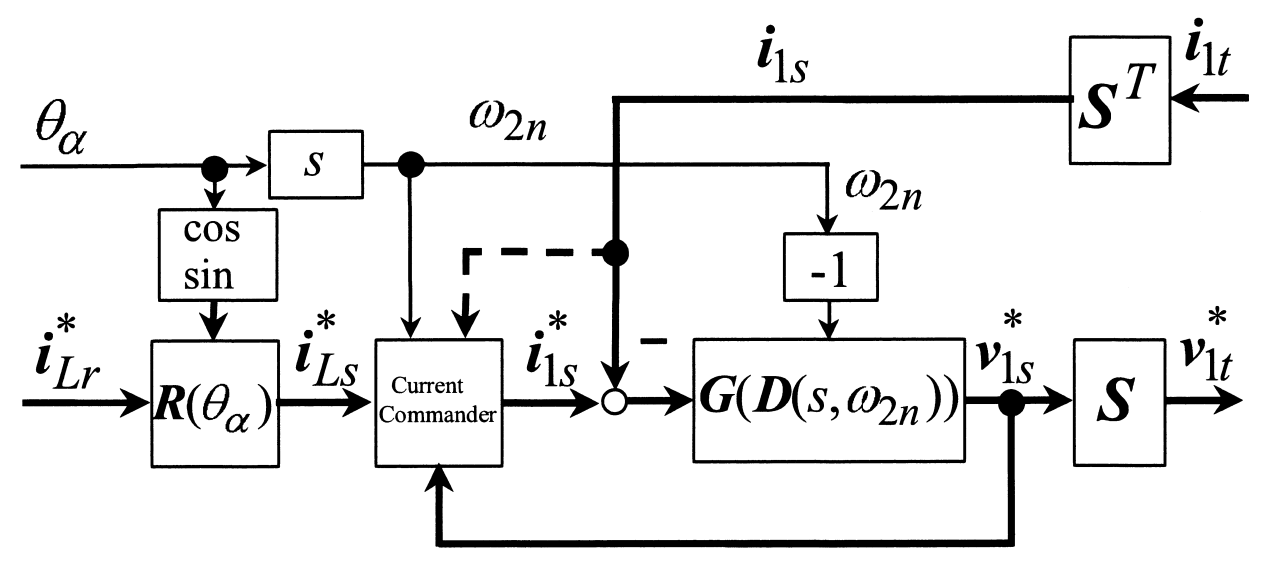

図 72 入力 2 出力 $\mathrm{D}$ 因子制御器を利用した構造例

Fig. 7. A basic structure of vector control systems using a 2x2 D-controller.

ある。特に，電圧形電流指令器を用いたべクトル制御系に おいては，フィードバック制御ループは固定子電流制御の ためのループそのものであり，このための指令值も固定子 電流指令值となって抢り，固定子電流を直接的に制御する ものとなっている。固定子負荷電流の利用は，既に明らか にしたように，基本的に(20) 式の関係に基づいている。

図 3, 図 4, 四 6 に打ける指令変換器 (command converter と表示）は，トルク指令值から負荷電流指令值を生成する 役割を担っている。本指令変換器は, 高効率駆動あるいは 広範囲駆動の観点から構成すればよく(3), 図 3, 図 4, 図 6 のベクトル制御系は，本指令変換器に如何なる制約も要求 しない。すなわち, 本指令変換器は, ベクトル制御系の構 造に影響されることなく, 発生トルクと固定子負荷電流と の関係を定めたトルク発生式（第 2 基本式）(3) 式に従っ て, 独立的に設計・構成することができる。指令変換器の 入力であるトルク指令值は, トルク制御の場合には直接与 えればよく，上位に速度制御系を構成する場合には速度制 御器の出力として得ればよい。このように，提案のベクト ル制御系は，高い沉用性を確立している。

$\langle\mathbf{3} \cdot \mathbf{3}\rangle$ D 因子制御器を用いたベクトル制御系 図 3, 図 4, 図 6 のいずれのベクトル制御系においても，1対の相 変換器と 1 対のベクトル回転器を利用した伝統的な構造を 採用した。これに代わって，2 入力 2 出力 $\mathrm{D}$ 因子制御器を 用いてベクトル制御系を構成することも可能である(20)。電 圧形負荷電流発生器を $\alpha \beta$ 固定座標系上で構成した図 4 に おいては，1対のベクトル回転器を排除した形で D 因子制 御器を導入することができる。また，電圧形負荷電流発生 器を uvw 座標系上で構成するならば，1 対のベクトル回転 器と 1 対の相変換器とを排除した形で 3 入力 3 出力 $\mathrm{D}$ 因子 制御器を導入することができる(20)。

図 6 のベクトル制御系に対応した形で, 2 入力 2 出力 $\mathrm{D}$ 因 子制御器を用いたべクトル制御系を構成することも可能で ある。電流制御ループの変更は, 鉄損を無視した SP-PMSM の場合の変更と完全同一である。D 因子制御器導入の若干 の注意点は，電圧形電流指令器にあるにすぎない。すなわ
ち, D 因子制御器の導入により 1 対のベクトル回転器を排 除する場合には, 図 5 の電圧形電流指令器において, 電圧形 電流指令器の入力信号はすべて $\alpha \beta$ 固定座標系上の信号と する必要がある。当然，その出力も同座標系上の信号とな る。図 7 は, この種の D 因子制御器 $\boldsymbol{G}(\boldsymbol{D}(\cdot, \cdot))$ を用いたべ クトル制御系であり，図 6 のベクトル制御系に対応してい る。図 6 の非干渉器を有しない電流制御器 (26) 式に対応し た D 因子制御器 $\boldsymbol{G}(\boldsymbol{D}(\cdot, \cdot))$ は次式となる（詳細は文献 (20) 参照)。

$$
\boldsymbol{G}\left(\boldsymbol{D}\left(s, \omega_{2 n}\right)\right)=K_{p} \boldsymbol{I}+K_{i} \boldsymbol{D}^{-1}\left(s, \omega_{2 n}\right)
$$

図 7 に打ける電圧形電流指令器の構造は図 5 と同一であ るが，その入出力信号は $\alpha \beta$ 固定座標系上の信号となって いる点には注意されたい。

3 入力 3 出力 $\mathrm{D}$ 因子制御器導入により 1 対のベクトル回 転器と 1 対の相変換器とを排除する場合のループ内構造は, 鉄損を有しない場合 ${ }^{(20)}$ と同一である。この場合の電圧形電 流指令器の構造も図 5 と同一であるが, その入出力信号は uvw 座標系上の信号となる。

\section{4. 新構造の定量的検証と設計例}

$\langle 4 \cdot 1\rangle$ システム構造と試験条件 提案構造をもつ心゙ クトル制御系により，固定子負荷電流が適切に制御され，ひ いては発生トルク, 固定子電流が制御されることをシミュ レーションにより検証・確認する。併せて, 具体的な設計 例を示す。図 8 にシミュレーションのためのベクトル制御 系を示した。本べクトル制御系は, 図 3 に示した電圧形負 荷電流発生器を有するべクトル制御系を模擬したものであ る。制御対象である SP-PMSM は，文献 (21) によって提示 された $\mathrm{A}$ 形べクトルブロック線図に基づくベクトルシミュ レータを利用して構成した。SP-PMSM には負荷装置を連 結し，SP-PMSM の速度を負荷装置により制御できるよう にした。電力変換器 (ideal 2-phase inverter と表示) は, 伝 達関数が 1 の理想的特性をもつ 2 相変換器とした。

シミュレーションに使用した供試モー夕の特性は，提案 


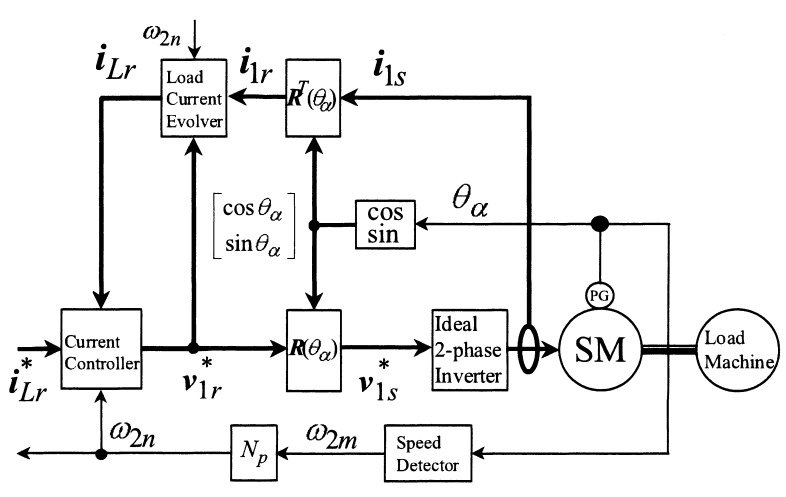

図 8 シミュレーションシステム

Fig. 8. A simulation system.

表 1 供試モー夕の特性

Table 1. Characteristics of test motor.

\begin{tabular}{|l|l|l|l|}
\hline$R_{1}$ & $2.259(\Omega)$ & rated torque & about $2.2(\mathrm{Nm})$ \\
\hline$R_{c}$ & $100(\Omega)$ & rated speed & $183(\mathrm{rad} / \mathrm{s})$ \\
\hline$L_{i}$ & $0.02662(\mathrm{H})$ & rated current & $1.7(\mathrm{~A}, \mathrm{rms})$ \\
\hline$L_{m}$ & $-0.00588(\mathrm{H})$ & rated voltage & $163(\mathrm{~V}, \mathrm{rms})$ \\
\hline$\Phi$ & $0.24(\mathrm{~V} \mathrm{~s} / \mathrm{rad})$ & moment of inertia & $0.0016\left(\mathrm{kgm}^{2}\right)$ \\
\hline$N_{p}$ & 3 & rated power & $400(\mathrm{~W})$ \\
\hline
\end{tabular}

構造の妥当性を平易かつ明瞭に検証・確認すべく, 小さめ な等価鉄損抵抗（すなわち，大きな鉄損を生じる等価鉄損 抵抗）をもつ表 1 のもとした。本供試モー夕に対して電 流制御ループの带域幅が約 $2000(\mathrm{rad} / \mathrm{s})$ が得られるように PI 制御器パラメータを以下のように設計した。

$$
K_{p}=53.24, \quad K_{i}=9583
$$

$\mathrm{dq}$ 同期座標系上の電圧形負荷電流発生器は, (21) 式に従っ て構成した。このときの固定子電圧近似值 $\boldsymbol{v}_{1}^{\prime} に は,(23 b)$ 式に示した，固定子電圧指令值のフィル夕処理值を用いた。 また，このときのフィルタ $G_{v}(s)$ としては, 電流制御ルー プ带域の 2 倍の带域をもつ次の 1 次とした。

$$
G_{v}(s)=\frac{4000}{s+4000}
$$

$\langle\mathbf{4} \cdot \mathbf{2}\rangle$ 電圧形負荷電流発生器を用いた制御系の性能例
A. 非干渉器を併用した応答の第 1 例
(24) 式に従い,

PI 制御器と非干渉器とを用いた電流制御器を構成した。す なわち, 非干渉器には固定子負荷電流を利用した。PI 制御 器のパラメー夕值は，(32) 式の通りである。

固定子負荷電流の制御性能を検証・確認するための試験 は, 以下のように行った。先ず, 負荷装置を用い, 供試 SPPMSM をこの定格速度近傍值である $180(\mathrm{rad} / \mathrm{s})$ の一定速 度で駆動した。この間，固定子負荷電流指令值にはゼロを 与え, 固定子負荷電流の $\mathrm{d}$ 軸, $\mathrm{q}$ 軸成分はゼ口状態に維持 した。この上で，ある瞬時に固定子負荷電流指令值の $\mathrm{q}$ 軸 成分に一定値 $3(\mathrm{~A})$ を与え，一方で $\mathrm{d}$ 軸成分はゼロを維持 した。すなわち，

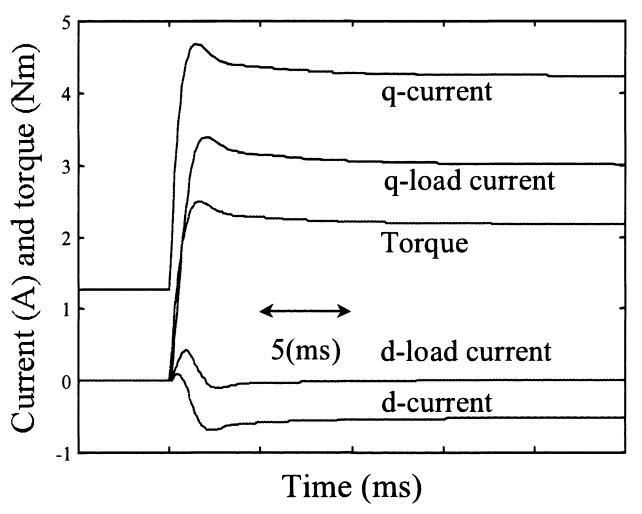

図 9 固定子負荷電流を用いた非干渉器を 併用した制御応答例

Fig. 9. Response examples of current control with decoupler using stator load current.

$$
\left[\begin{array}{l}
i_{L d}^{*} \\
i_{L q}^{*}
\end{array}\right]=\left[\begin{array}{l}
0 \\
3
\end{array}\right]
$$

応答結果を図 9 に示す。同図の波形は，上から，固定子 電流 $\mathrm{q}$ 軸成分, 固定子負荷電流 $\mathrm{q}$ 軸成分, 発生卜ルク, 固定 子負荷電流 $\mathrm{d}$ 軸成分, 固定子電流 $\mathrm{d}$ 軸成分である。ステッ プ状の負荷電流 $\mathrm{q}$ 軸成分指令值の変化に対して, 負荷電流 $\mathrm{d}$ 軸成分に若干の摇らぎが出現しているが, 摇らぎは $2(\mathrm{~ms})$ 程度で収斂し, 実質的に非干渉化が達成されている。

発生トルクとしては概ね定格值が得られているが，本值 は, トルク発生式 (3) 式を $\mathrm{dq}$ 同期座標系上で評価した次の 関係と合致するものである。

$$
\tau=N_{p}\left(2 L_{m} i_{L d}+\Phi\right) i_{L q}
$$

固定子負荷電流がゼロ状態でも, SP-PMSM の回転に起 因して, 固定子電流の $\mathrm{q}$ 軸電流が流れている点, (34) 式の 指令印加後には固定子電流 $q$ 軸成分, $d$ 軸成分は, 各々正, 負の方向へ大きくなっている点には, 注意されたい。固定 子負荷電流に対する固定子電流の増加分は, 固定子鉄損電 流に対応している。本応答結果は, 定常状態では次式のよ うに解析され(4)(5)，解析結果とも一致している。

$$
\begin{aligned}
\boldsymbol{i}_{1} & =\boldsymbol{i}_{L}+\boldsymbol{i}_{R}=\boldsymbol{i}_{L}+\frac{\boldsymbol{D}\left(0, \omega_{2 n}\right) \boldsymbol{\phi}_{1}}{R_{c}} \\
& =\left[\begin{array}{c}
i_{L d}-\frac{\omega_{2 n} L_{q} i_{L q}}{R_{c}} \\
i_{L q}+\frac{\omega_{2 n}\left(L_{d} i_{L d}+\Phi\right)}{R_{c}}
\end{array}\right] \ldots \ldots
\end{aligned}
$$

すなわち, 固定子負荷電流の制御を通じて, 発生トルクと 同様に，固定子電流も制御されている。

(注 2) 定常状態関係式 (36) 式が明示しているように, 固定 子鉄損電流は，等価鉄損抵抗のみでは定まらない。 固定子鉄損電流を固定子負荷電流との関係で評価す る場合には, これは, 等価鉄損抵抗に加え, 電気速 度, dq 固定子インダクタンス, 回転子磁束強度の関 数となる。本事実は, 固定子負荷電流に対する固定 


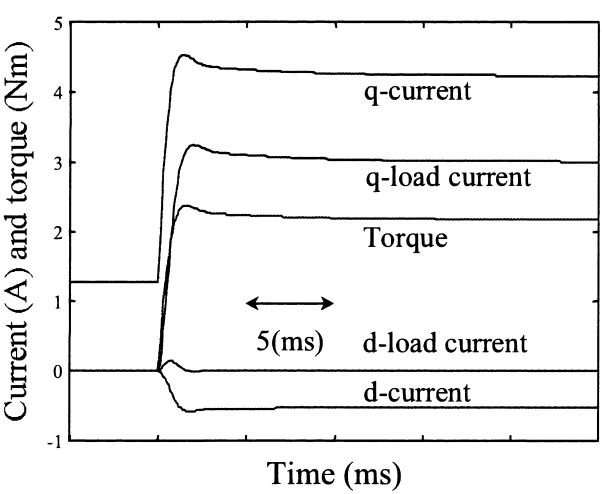

図 10 固定子電流を用いた非干渉器を併用した 制御応答例

Fig. 10. Response examples of current control with decoupler using stator current.

子鉄損電流の大きさの把握には，等価鉄損抵抗に加 え，これらパラメータと速度の把握も同時に必要で あること意味している。なお，表 1 の供試モータパ ラメータは，既に明記したように提案構造の検証・ 確認がし易いように小さいめな等価鉄損抵抗を利用 している点, ひいては固定子負荷電流が大きく出て いる点には，注意されたい。

B. 非干渉器を併用した応答の第 $\mathbf{2}$ 例 非干渉器に利 用する電流の違いを調べるためのシミュレーション実験を 行った。非干渉器には, 固定子負荷電流に代わって, 固定 子電流そのものを利用した。すなわち，(25) 式に従い電流 制御器を構成した。応答の結果を図 10 に示す。波形の意 味は, 図 9 と同一である。ステップ状の負荷電流 $\mathrm{q}$ 軸成分 指令值の変化時に扔ける固定子負荷電流 $\mathrm{d}$ 軸成分の摇らぎ が，図 9 のもの上に抑えられており，非干渉化性能の向 上が確認される。

C. 非干渉器を用いない応答例 非干渉器を撤去して, 同様のシミュレーション実験を行った。PI制御器の構成は, 非干渉器を併用した場合と同一である。応答の結果を図 11 に示す。波形の意味は，図 9, 図 10 と同一である。非干渉 器の撤去により, ステップ状の固定子負荷電流 q 軸成分指 令值の印加に応じ，固定子負荷電流 $\mathrm{d}$ 軸成分に大きめな変 動が出現している。また，同 $\mathrm{d}$ 軸成分のゼロへの収斂時間 も非干渉器を用いた場合より数倍長くなっている。しかし， トルク応答值は良好である。定常応答に関しては，非干渉 器を用いない場合と用いた場合との違いはない。

D. ゼロ速度における応答例（18）式に示したように， 鉄損は周波数依存性を有し，ゼ口周波数では鉄損は発生し ない。換言するならば，ゼロ周波数では固定子鉄損電流は ゼロとなり, 固定子負荷電流は固定子電流そのものとなる。 提案べクトル制御系による本特性を検証・確認すべくシミュ レーション実験を行った。実験条件は，回転子速度の違い を除けば，図 9〜図 11 の場合と同一である。ゼロ速度の場 合には非干渉器の有無の違いはない（(24)-(26) 式参照)。

実験結果を図 12 に示す。波形の有無は前図と同一であ

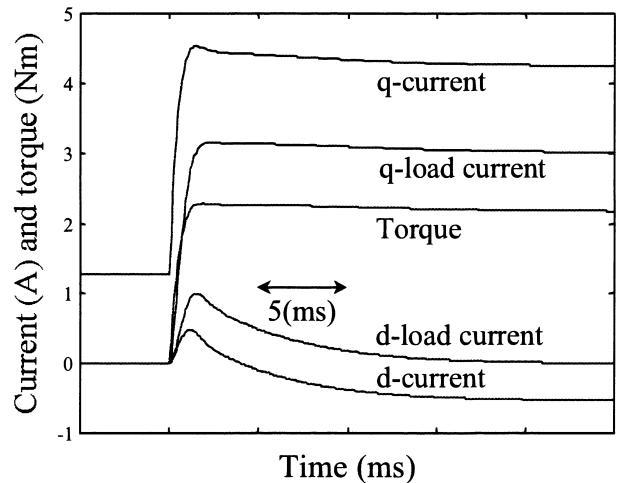

図 11 非干渉器を用いない制御応答例

Fig. 11. Response examples of current control with no decoupler.

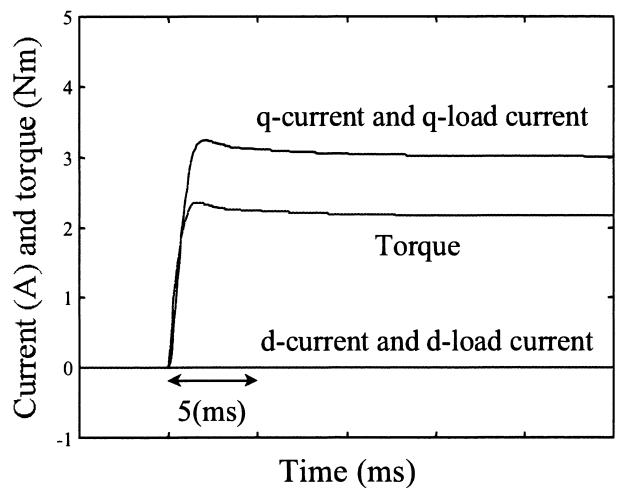

図 12 ゼロ速度での制御応答例

Fig. 12. Response examples of current control at standstill.

る。図より, 固定子電流は固定子負荷電流と同一となって おり，鉄損の影響は消滅していることが確認される（(36) 式参照)。すなわち, 提案のベクトル制御系は所期の制御性 能を発揮していることが確認される。

$\langle\mathbf{4} \cdot \mathbf{3}\rangle$ 電圧形電流指令器を用いた制御系の性能例 上 記の $\mathrm{A} \sim \mathrm{D}$ 項までのすべてのシミュレーション実験は，電 圧形負荷電流発生器を用いた図 3 のベクトル制御系に対応 したものであった。これに代わって, 電圧形電流指令器を 用いた図 6 のベクトル制御系に対応した実験を行い，前実 験との違いを検証・確認した。シミュレーション実験のた めのベクトル制御系は, 図 8 と同様に構成した。電圧形電 流指令器としては, (30b) 式に立脚した図 5(b) に従い構成 した。〈4·2〉節 $\mathrm{A} \sim \mathrm{D}$ 項と同一内容の実験を行った結果, 電圧形負荷電流発生器を用いた実験結果との有意の差異は 発見されなかった。

\section{5. おわりに}

本論文は，SP-PMSM のための鉄損を考慮したベクトル 制御系のあるべき構造を検討し, 新構造のものを提案した。 提案のベクトル制御系は，以下のような特徵をもつもので あった。(a) 提案べクトル制御系は, 固定子負荷電流の制御 
を通じて固定子電流を制御する構造を採用している。(b) 提 案ベクトル制御系は，固定子負荷電流制御の平易な遂行を 実現すべく固定子電圧を常時フィードバック利用する構造 を採用している。(c) 提案構造では, 鉄損分を排除した固定 子負荷電流の制御を通じ，精度の高いトルク制御が可能で ある。(d) トルク指令值から負荷電流指令值の生成を担う電 流指令法も種々のものが利用可能である。(e) 提案ベクトル 制御系は, トルク制御と同時に速度制御にも適用可能であ り，線形性の良い速度制御系の構成が可能である。上記特 徵をもつ提案べクトル制御系の今後の活用が期待される。 (平成 19 年 8 月 27 日受付, 平成 19 年 10 月 19 日再受付)

\section{文献}

(1) S. Shinnaka: "Proposition of New Mathematical Models with Core Loss Factor for Controlling AC Motors", Proc. of the 24-th Annual Conference of the IEEE Industrial Electronics Society (IECON'98)), pp.297-302 (1998-9)

(2) S. Shinnaka: "A New Mathematical Model with Parallel Core-Loss Factor for Salient-Pole Synchronous Motor", Trans. of Society of Instrument and Control Engineers (T. SICE), Vol.36, No.2, pp.223-225 (2000-2) (in Japanese)

新中新二：「統一固定子モデルに立脚した突極形同期モー夕の並列 形鉄損項をもつ新数学モデルの構築」, 計測自動制御学会論文集, 36, 2, pp.223-225 (2000-2)

(3) S. Shinnaka: "New Practical Optimal Current Control Methods for EnergyEfficient Wide-Speed-Range Operation of Salient-Pole Permanent Magnet Synchronous Motor with Core-Losses", IEEJ Trans. IA, Vol.123, No.11, pp.1359-1370 (2003-11) (in Japanese)

新中新二:「突極形永久磁石同期モー夕の広範囲高効率運転のための鉄 損を考慮した実用的最適電流指令法」, 電学論 D, 123, 11, pp.1359-1370 (2003-11)

(4) Y. Tong, J. Morimoto, S. Morimoto, Y. Takeda, and T. Hirasa: "High Efficinecy Control of Brushless DC Motors for Energy Saving", IEEJ Trans. IA, Vol.112, No.3, pp.285-291 (1992-3) (in Japanese) 童㲔・森本純司・森本茂雄・武田洋次・平紗多賀男:「ブラシレス DC モータの省エネルギー高効率運転法」, 電学論 D, 112, 3, pp.285-291 (1992-3)

(5) S. Morimoto, Y. Tong, Y. Takeda, and T. Hirasa: "Loss Minimization Control of Permanent Magnet Synchronous Motor Drives", IEEE Trans. Industrial Electronics, Vol.41, No.5, pp.511-517 (1994-10)

(6) R.C. Panaitescu and I. Topa: "Optimal Control Method for PMSM by Minimization of Electrical Losses", Proc. of the 6-th International Conference on Optimization of Electrical and Electronics Equipments (OPTIM'98), Vol.2, pp.451-456 (1998-3)

( 7 ) R. Monajemy and R. Krishman: "Control and Dynamics of Constant-PowerLoss-Based Operation of Permanent-Magnet Synchronous Motor Drive System", IEEE Trans. Industrial Electronics, Vol.48, No.4, pp.839-844 (20018)

(8) C. Mademlis, J. Xypteras, and N. Margaris: "Loss Minimization in Surface Permanent-Magnet Synchronous Motor Drives", IEEE Trans. Industrial Electronics, Vol.47, No.1, pp.115-122 (2000-2)

(9) C. Mademlis and N. Margaris: "Loss Minimization in Vector-Controlled Interior Permanent-Magnet Synchronous Motor Drives", IEEE Trans. Industrial Electronics, Vol.49, No.6, pp.1344-1347 (2002-12)

(10) C. Cavallaro, A.O. Di-Tommaso, R. Miceli, A. Raciti, G.R. Galluzzo, and M. Trapanese: "Analysis a DSP Implementation and Experimental Validation of a Loss Minimization Algorithm Applied to Permanent Magnet Synchronous Motor Drives", Proc. of the 29-th Annual Conference on the IEEEE Industrial Electronics Society (IECON'03), Vol.1, pp.312-317 (2003-11)

(11) C. Cavallaro, A.O. Di-Tommaso, R. Miceli, A. Raciti, G.R. Galluzzo, and M. Trapanese: "Efficiency Enhancement of Permanent-Magnet Synchronous Motor Drives by Online Loss Minimization Approaches", IEEE Trans. Industrial Electronics, Vol.52, No.4, pp.1153-1160 (2005-8)

(12) N.R. Abjadi, J. Soltani, M. Pahlavaninezhad, and J. Askari: "A Nonlinear Adaptive Controller for Speed Sensorless PMSM Taking the Iron Loss Resistance into Account", Proc. of the 8-th International Conference on Electrical Machines and Systems (ICEMS 2005), Vol.1, pp.188-193 (2005-9)
(13) T. Senju, T. Shimabukuro, and K. Uezato: "Vector Control of Permanent Magnet Synchronous Motors Including Stator Iron Loss", Proc. of the IEEE International Conference on Industrial Technology (ICIT 1994), pp.1-5 (1994-12)

(14) T. Senju, T. Shimabukuro, N. Urasaki, and K. Uezato: "Vector Control of PMSM with On-Line Parameter Measurement Including Stator Iron Loss", Proc. of the IEEE International Conference on Industrial Electronics Control and Instrumentation (IECON 1996), Vol.3, pp.1717-1722 (1996-8)

(15) T. Senju, N. Urasaki, and K. Uezato: "Influence of Stator Iron Loss in Flux Weakening Region for Interior PMSM”, Proc. of 1998 Power Electronics Drives and Energy Systems for Industrial Growth (PEDES 1998), Vol.1, pp.20-25 (1998-12)

（16）開道 力：「鋼板内磁気特性分布を考慮した電磁鋼板コアの等価回 路」, 日本応用磁気学会誌, Vol.19, No.1, pp.39-44 (1995-1)

（17）水野孝行 ·高山順一・市岡忠士 · 寺嶋正之：「固定子鉄損を考慮した 誘導電動機の非干渉制御法」, 電学論 D, 109, 11, pp.841-848 (1989-11)

（18）新中新二：「交流電動機のベクトル制御方法」, 日本国特許第 3994419 号 (1997-9-25)

（19）新中新二・千田 剛：「鉄損を有する誘導モータのための新数学モデ ルに基づくベクトル制御」, 平 10 電学全大講演論文集, 4, pp.316-317 (1998-3)

(20) S. Shinnaka: "New Vector Controller in the D-module for Three-Phase Systems", IEEJ Trans. IA, Vol.122, No.12, pp.1121-1128 (2002-12) (in Japanese)

新中新二：「三相システムのための D 因子ベクトルコントローラの 提案」, 電学論 D, 122, 12, pp.1121-1128 (2002-12)

(21) S. Shinnaka: "New Block Diagrams Using Vector Signals in the General Frame of Reference for AC Motors with Stator Core Losses", IEEJ Trans. IA, Vol.120, No.12, pp.1492-1500 (2000-12) (in Japanese) 新中新二：「固定子鉄損を有する交流モー夕の一般座標ベクトル信 号によるブロック線図」, 電学論 D, 120, 12, pp.1492-1500 (2000-12)

\section{付 録}

\section{トルク変動率}

鉄損を有するPMSM に対して，鉄損を無視したべクト ル制御を通じてトルク発生を行った場合に起きるトルク変 動の割合（トルク変動率）を以下に示す。

鉄損を有するPMSMにおいて，実際に発生されるトル クをてで，またPMSM に対して鉄損が無視できると仮定

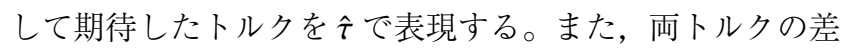
異を $\Delta \tau$ で表現する。

鉄損が無視しできると仮定して期待したトルクは, dq 同期 座標系上の信号を用い, 次のように展開することができる。

$$
\begin{aligned}
\hat{\tau} & =N_{p}\left(\Phi+2 L_{m} i_{d}\right) i_{q} \\
& =N_{p}\left(\begin{array}{l}
\left(\Phi+2 L_{m} i_{L d}\right) i_{L q} \\
+\left(\Phi+2 L_{m} i_{L d}\right) i_{R q}+2 L_{m} i_{q} i_{R d}
\end{array}\right)
\end{aligned}
$$$$
=\tau+\Delta \tau \ldots \ldots \ldots \ldots \ldots \ldots \ldots \ldots \ldots \ldots \ldots \ldots \ldots
$$

ただし，

$$
\Delta \tau=N_{p}\left(\left(\Phi+2 L_{m} i_{L d}\right) i_{R q}+2 L_{m} i_{q} i_{R d}\right) \cdots \cdots
$$

また， $i_{R d}, i_{R q}$ は固定子鉄損電流の $\mathrm{d}, \mathrm{q}$ 軸成分である。

従って, トルク変動率は, (付 1), (付 2) 式に (3) 式を考 慮すると, 次式のように求められる。

$$
\frac{\Delta \tau}{\tau}=\frac{i_{R q}}{i_{L q}}+\frac{2 L_{m} i_{q}}{\Phi+2 L_{m} i_{L d}} \cdot \frac{i_{R d}}{i_{L q}} \ldots \ldots \ldots \ldots \ldots
$$

ここで, PMSMは定常状態にあるとして, (36) 式に示した 固定子鉄損電流の $\mathrm{d}, \mathrm{q}$ 軸成分 $i_{R d}, i_{R q}$ を上式に用いると, 次式を得る。 


$$
\frac{\Delta \tau}{\tau}=\frac{\omega_{2 n}}{R_{c}}\left(\frac{\Phi+L_{d} i_{L d}}{i_{L q}}-\frac{2 L_{m} L_{q} i_{q}}{\Phi+2 L_{m} i_{L d}}\right) \cdots \cdots
$$

(付 4) 式における固定子電流 $\mathrm{q}$ 軸成分 $i_{q}$ は, 固定子負荷電 流と固定子鉄損電流との $\mathrm{q}$ 軸成分を有している点には注意 されたい。固定子電流 q 軸成分は (36) 式を活用し固定子負 荷電流 q 軸成分を用いて表現可能であるが，表現上の簡明 性を確保すべく，敢えて本表現方法を採用した。

(付 4) 式は，特に $L_{m}=0$ が成立する場合には，以下のよ うに整理される。

$$
\frac{\Delta \tau}{\tau}=\frac{i_{R q}}{i_{L q}}=\frac{\omega_{2 n}}{R_{c}} \cdot \frac{\Phi+L_{d} i_{L d}}{i_{L q}}
$$

(付 5) 式は，PMSM が非突極でありかつ固定子負荷電流 が一定と言う条件下では，トルク变動率は $\omega_{2 n} / R_{c}$ に比例す ることを意味する。突極性をもつ PMSM のトルク変動率 は，(付 4) 式が示めしているように，本比例関係は成立せ ず，複雑な動きをする。しかしながら，トルク変動率の具 体的な值は，トルク発生に寄与する固定子負荷電流に加え， 速度，モータパラメー夕を(付 4) 式に与えるならば，直ち に決定することができる。

なお，(付 4)，(付 5) 式は，本論文のみならず，文献 (2) (12)に示された，鉄損を考慮にいれたPMSM のベクトル 制御に挹いて共通に成立する関係である。この点には注意 されたい。
新 中 新 二（正員）1973 年防衛大学校卒業。同年陸上自衛

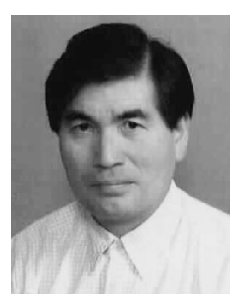
隊中央野外通信群入隊。1977 年 University of California，Irvine 大学院修士課程修了。1979 年同博 士課程修了。防衛庁技術研究本部第 1 研究所，防 衛大学校電気工学教室等での奉職を終えて, 1986 年陸上自衛隊を除隊。同年キヤノン（株）勤務。 1991 年ベンチャー研究所創設。1996 年神奈川大 学電気工学科勤務 (教授, 現電子情報フロンティ ア学科)。2002 年同学市民 EV センター創設 (代表)。これまでの間, 通信，情報，制御，パワーエレクトロニクス分野の教育，研究，開発 及びこれらの管理等に従事。近年はサーボモータ駆動制御技術の体 系化に専念し，2001 年に誘導モー夕を用いたセンサレスベクトル制 御駆動・トランスミッションレス電気自動車（ST-EV）の世界初開発 に成功。本功績により 2002 年計測自動制御学会より技術賞を受賞。 2003 年 IEEE IAS-Transactions 論文賞受賞。2004 年永久磁石同期モ一 夕を用いた ST-EV の世界初開発に成功。同期モータセンサレス駆動 制御における周波数ハイブリッド基本概念（日本国特許第 3612636 号 (1996.9.18))，ミール法基本概念 (日本国特許第 3735836 号 (2000.1.2), 第 3814826 号 (2004.12.10)), 最小次元磁束状態オブザーバ基本概念 （日本国特許第 3653670 号 (2002.8.31)), 鏡相推定基本概念（日本国特 許第 3328636 号 (2000.3.17), 第 3968688 号 (2000.11.28), 第 3968689 号 (2000.12.23)) , 鉄損を考慮したベクトル制御系構造（日本国特許第 3994419 号 (1997.9.25) ) 等を含む多くの基本技術の第 1 提唱者。計 測自動制御学会，IEEE，欧州 EPE，自動車技術会などの会員。Doctor of Philosophy 及び工学博士。 